\title{
Chloroplast Proteome of Nicotiana benthamiana Infected by Tomato Blistering Mosaic Virus
}

\author{
Esau Megias ${ }^{1}$ - Lílian Silveira Travassos do Carmo ${ }^{1} \cdot$ Cícero Nicolini $^{2} \cdot$ Luciano Paulino Silva $^{1} \cdot$ Rosana Blawid $^{3}$. \\ Tatsuya Nagata $^{3} \cdot$ Angela Mehta $^{1}$
}

Published online: 25 May 2018

○) Springer Science+Business Media, LLC, part of Springer Nature 2018

\begin{abstract}
Tymovirus is a genus of plant pathogenic viruses that infects several dicotyledonous plants worldwide, causing serious diseases in economically important crops. The known cytopathic effect on the host cell organelles involves chloroplast membrane deformation and the induction of vesicles in its periphery. These vesicles are known to be the location where tymoviral genomic RNA replication occurs. Tomato blistering mosaic virus (ToBMV) is a tymovirus recently identified in tomato plants in Brazil, which is able to infect several other plants, including tobacco. In this work, we investigated the chloroplast proteomic profile of ToBMV-infected $N$. benthamiana using bidimensional electrophoresis (2-DE) and mass spectrometry, aiming to study the virus-host interaction related to the virus replication and infection. A total of approximately 200 spots were resolved, out of which 36 were differentially abundant. Differential spots were identified by mass spectrometry including photosynthesis-related and defense proteins. We identified proteins that may be targets of a direct interaction with viral proteins, such as ATP synthase $\beta$ subunit, RNA polymerase beta-subunit, 50S ribosomal protein L6 and Trigger factor-like protein. The identification of these candidate proteins gives support for future protein-protein interaction studies to confirm their roles in virus replication and disease development.
\end{abstract}

Keywords Plant proteomics $\cdot$ Plant-virus interaction $\cdot$ ToBMV $\cdot 2$-DE $\cdot$ Mass spectrometry

\section{Introduction}

Tymovirus are single-stranded RNA viruses with positive sense that infect mainly dicotyledonous plants, including those from families Cucurbitaceae, Brassicaceae and Solanaceae, and cause serious diseases [1]. The genus Tymovirus comprises a total of 35 confirmed species, and belongs to the Tymoviridae family, which includes the Maculavirus and Marafivirus genera. In Brazil, five Tymovirus species have been reported: Eggplant mosaic virus [2], Petunia

Esau Megias and Lílian Silveira Travassos do Carmo have contributed equally to the work.

Angela Mehta

angela.mehta@embrapa.br

1 Embrapa Recursos Genéticos e Biotecnologia, Av. W5 Norte final, Brasília, DF 70770-917, Brazil

2 Universidade Estadual do Piauí, Teresina, PI, Brazil

3 Departamento de Biologia Celular, Instituto de Biologia, Universidade de Brasília, Brasília, DF, Brazil vein-banding virus [3], Passion fruit yellow mosaic virus [4], cassia yellow mosaic-associated virus [5], and tomato blistering mosaic virus (ToBMV) [6].

ToBMV was isolated from Santa Catarina state, Brazil and tentatively named as tomato blistering mosaic virus (ToBMV) [7]. ToBMV was also able to infect several other plants, including Nicotiana tabacum, N. benthamiana, Capsicum annuum and Solanum violaefolium $[8,9]$. This virus species was always found in virome studies in tomato and pepper plants using Next-generation sequencing (Tatsuya Nagata, unpublished data) and, therefore it is essential to investigate and understand the effects of this virus in the host plant since it represents a serious threat to tomato and pepper producing areas. A recent report revealed the detection of this virus affecting tomato in Argentina, which has a serious epidemiological impact [10]. A phylogenetic analysis was also performed and showed that ToBMV clustered with other common tymoviruses that infect solanaceous hosts [6, 7]. Recently, the complete genome of ToBMV was sequenced $[6,8,9]$ revealing a size of about $6.3 \mathrm{~kb}$ and three ORFs: ORF 1 encodes the RNA replication polyprotein, 
(cleaved to metyltransferase/protease, helicase, and RNAdependent RNA polymerase), ORF 2 the movement protein, and ORF 3 the coat protein. ToMBV causes the typical cytopathic effects usually seen on tymovirus infected tissue, including double-membrane vesicles on the periphery of the chloroplasts [7]. The vesicles, caused by tymoviruses, are the sites where viral genome replication occurs. In general, an RNA virus replicates on the surface of the organelle and (in many cases) viral replication-related proteins, such as helicase, methyltransferase or viral RNA-dependent RNA polymerase, interact directly with the host organelle membrane proteins. This replication site known as the virus replication complex (VRC) often forms vesicles, escaping from the RNA degradation pressure of plant cells by RNAi machinery [11].

During the last 10 years, more focus has been given to identify the host gene expression changes during viral infection using different functional genomic techniques, including proteomics based on bidimensional electrophoresis (2-DE) and liquid chromatography (LC) coupled to mass spectrometry (MS). Research in proteomics of plant-virus interactions has been extensively reviewed in Di Carli et al. [12]. In order to get a better view of plant responses to biotic and abiotic stresses, recent studies have focused on organelle subproteomes, such as those of chloroplast and mitochondria. 2-DE has proven to successfully reveal the protein profiles of both luminal and peripheral thylakoid proteins from Pisum sativum [13] and Arabidopsis thaliana [14]. However, much less is known about the effects that different biotic and abiotic-stress factors have on the chloroplast proteome. In virus-plant interaction, a study of the interaction between $N$. benthamiana and pepper mild mottle virus (PMMoV, genus Tobamovirus) pointed out changes in the abundance of several photosynthetic proteins as well as proteins of the Benson-Calvin cycle, nitrogen metabolism, and protein synthesis [15].

The most common symptoms of viral infection observed in plants are chlorosis and reduction in photosynthesis. In the case of ToBMV, due to the strong chloroplast interaction, photobleaching (whitening leaves) is also observed when the symptoms are very severe, probably as a result of compromised chlorophyll synthesis [7]. Several reports showed the down-regulation of photosynthetic proteins by viral proteins (reviewed in [16]), and the identification of these targets is one on the main goals in plant-virus interaction studies. ROS production and scavenging, for example, are important responses during plant-virus interaction and are crucial for disease resistance. Brizard et al. [17] copurified different peroxidases with viruses from Rice yellow mottle virus resistant and susceptible rice and showed that viruses recruit many host proteins for their development. Chloroplasts are also the crucial site for hormone production, such as salicylic (SA) and jasmonic (JA) acids
$[18,19]$, involved in plant defense systems against viruses [20]. Proteins involved in photosynthetic electron-transport chain and the Benson-Calvin cycle were also reported in $N$. benthamiana in response to the PMMoV Spanish strain by analyzing the chloroplast proteome by 2-DE [15]. Although some chloroplast proteins interacting with virus proteins have been identified, the knowledge of this interaction is still limited. The understanding of chloroplast-virus interaction can certainly bring new insights for the elucidation of the tymovirus replication and infection mechanisms. Thus, considering the importance of plant chloroplast proteins in viral infection and development, the objective of the present work was to study the chloroplast subproteome of the host plant $N$. benthamiana (model plant for plant virology) upon ToBMV infection by 2-DE in order to obtain a new insight of the processes affected by this virus.

\section{Materials and Methods}

\subsection{ToBMV Plant Inoculation and Chloroplast Enrichment}

Nicotiana benthamiana plants cultivated in glasshouse at $\pm 25{ }^{\circ} \mathrm{C}$ for 30 days were mechanically inoculated with ToBMV infected sap in phosphate buffer $\mathrm{pH} 7.2$ with $0.2 \%$ of sodium sulfide and carborundum. The same mechanical damage with phosphate buffer and abrasive carborundum was applied to non-inoculated control plants. Three biological replicates were obtained for each sample and used for chloroplast enrichment.

Leaves were collected 10 days after inoculation, when plants started showing intense systemic symptoms, as determined by de Oliveira et al. [7]. Plants were maintained in a dark room for $24 \mathrm{~h}$ before leaves were harvested to reduce starch accumulation. Chloroplast enrichment was performed on collected leaves using Chloroplast Isolation Kit (SigmaAldrich, St. Louis, USA), with minor modifications. Fresh leaves were blended two to five times for $5 \mathrm{~s}$ in Chloroplast Isolation Buffer (CIB) 6:1 v:w (g) (0.3 M sorbitol, $5 \mathrm{mM}$ $\mathrm{MgCl}_{2}, 5 \mathrm{mM}$ EGTA, $5 \mathrm{mM}$ EDTA, $20 \mathrm{mM}$ HEPES/KOH, $\mathrm{pH} 8.0,10 \mathrm{mM} \mathrm{NaHCO}$ ) [21]. The blended leaf sap was filtered in nylon cloth and centrifuged in $50 \mathrm{~mL}$ tubes at $1000 \times g$ at $4{ }^{\circ} \mathrm{C}$ for $7 \mathrm{~min}$ to sediment the chloroplasts. The supernatant was discarded and the green pellet was suspended in CIB. A Percoll (GE HealthCare) gradient $40 \% / 80 \%$ diluted in CIB was prepared by centrifugation at $3200 \times g$ for $15 \mathrm{~min}$ at $4{ }^{\circ} \mathrm{C}$. The intact chloroplasts at the interface between the 40 and $80 \%$ Percoll layers were collected, visualized by light microscope and stored at $-80^{\circ} \mathrm{C}$. 


\subsection{Chloroplast Protein Extraction and Quantification}

Chloroplast protein extraction was performed according to Carmo et al. [22]. For each $100 \mu \mathrm{L}$ of purified chloroplast $750 \mu \mathrm{L}$ of extraction buffer $(0.7 \mathrm{M}$ sucrose, $0.5 \mathrm{M}$ Tris $-\mathrm{HCl}$, $30 \mathrm{mM} \mathrm{HCl}, 50 \mathrm{mM}$ EDTA, $0.1 \mathrm{M} \mathrm{KCl}, 40 \mathrm{mM}$ DTT) were used. Samples were incubated for $15 \mathrm{~min}$ at room temperature and $750 \mu \mathrm{L}$ of phenol were added. Samples were maintained under agitation in a vortex mixer for $15 \mathrm{~min}$ and centrifuged at $8050 \times \mathrm{g}$ for $3 \mathrm{~min}$. This step was repeated with $500 \mu \mathrm{L}$ of phenol. Proteins were precipitated with $0.1 \mathrm{M}$ ammonium acetate in methanol and washed with $80 \%$ acetone. Proteins were suspended in solubilization buffer $(7 \mathrm{M}$ urea; $1 \mathrm{M}$ thiourea; 4\% m/v CHAPS; 2\% IPG buffer $\mathrm{pH}$ 3-10 $\mathrm{NL} ; 40 \mathrm{mM}$ DTT). Protein quantification was performed using Bio-Rad Protein Assay Dye Reagent Concentrate (Bio-Rad), according to the manufacturer's instructions.

\subsection{2-DE and Image Analysis}

A total of $400 \mu \mathrm{g}$ of extracted proteins were used to rehydrate $13 \mathrm{~cm}$ Immobiline DryStrips, pH 3-10 NL for $16 \mathrm{~h}$. Isoelectric focusing was performed using GE ${ }^{\mathrm{TM}}$ Healthcare Ettan ${ }^{\mathrm{TM}}$ IPGphor ${ }^{\mathrm{TM}} 3$ Isoelectric Focusing System (GE Healthcare Life Sciences, Issaquah, USA), according to the manufacturer's instructions (step 1: $500 \mathrm{~V}, 60 \mathrm{~min}, 0.5 \mathrm{kVh}$; step 2: $1000 \mathrm{~V}, 60 \mathrm{~min}, 0.8 \mathrm{kVh}$; step 3: $8000 \mathrm{~V}, 150 \mathrm{~min}, 11.3 \mathrm{kVh}$; step 4: $8000 \mathrm{~V}, 55 \mathrm{~min}, 7.4 \mathrm{kVh}$ ). IPG strips were maintained in equilibration buffer [1.5 M Tris- $\mathrm{HCl} \mathrm{pH} \mathrm{8.8;6} \mathrm{M}$ urea; $30 \%$ (v/v) glycerol; $2 \%$ (w/v) SDS; $1 \%$ (v/v) bromophenol blue] with $1 \mathrm{M}$ DTT for $15 \mathrm{~min}$ followed by $15 \mathrm{~min}$ in the same buffer containing $2.5 \%(\mathrm{w} / \mathrm{v})$ iodoacetamide. The second dimension was performed on $12 \%$ polyacrylamide gel and the electrophoresis was run in a vertical system (Biometra V2) with glycine buffer [20 mM Tris $\mathrm{HCl} \mathrm{pH} \mathrm{8.3,}$ $192 \mu \mathrm{M}$ glycine and $0.1 \%$ (w/v) SDS]. Benchmark Protein Ladder (Thermo Fisher Scientific, Waltham, USA) was used as molecular mass marker. Gels were stained overnight with colloidal Coomassie Blue [0.1\% (w/v) Coomassie G250; $2 \%$ (v/v) phosphoric acid; $10 \%(\mathrm{w} / \mathrm{v})$ ammonium sulphate; and $20 \%$ (v/v) methanol] and destained with Milli-Q water.

One gel from each biological replicate was digitalized with the ImageScanner III (GE Healthcare Life Sciences) according to the manufacturer's instructions. Images were analyzed using the software ImageMaster ${ }^{\mathrm{TM}}$ 2D Platinum v7.0 (GE Healthcare Life Sciences). Spots were automatically detected and a manual adjustment was performed to minimize possible technical artifacts. Automated matching was performed and matches were manually checked in order to minimize possible errors. Only proteins present in, at least, two out of three replicates were considered for analysis. Spot quantification was performed using intensity, area, volume, and relative volume, according to ImageMaster ${ }^{\text {TM }}$ 2D Platinum v7.0. Proteins were considered as differentially abundant only when differences were significant by Student's $t$ test at a significance level of $95 \%$.

\subsection{Protein Identification by MS}

The differentially abundant proteins were excised from the gel and hydrolyzed using Trypsin Profile IGD kit (SigmaAldrich), according to manufacturer's instructions. A total of $0.4 \mu \mathrm{g}$ of trypsin was added to each spot and the digestion was incubated overnight at $37{ }^{\circ} \mathrm{C}$. After the digestion, $1 \mu \mathrm{L}$ of the solution was mixed with $1 \mu \mathrm{L}$ of alpha-cyano4-hydroxycinnamic acid $(10 \mathrm{mg} / \mathrm{mL}$ in $50 \%$ acetonitrile and $0.1 \%$ trifluoroacetic acid) and applied manually onto an Anchorchip 800/384 MALDI target plate. Peptides were analyzed using Ultra-Flex III or Auto-Flex Speed MALDI TOF-TOF mass spectrometers (Bruker Daltonics, Billerica, USA) operating in positive reflector (MS) and LIFT TM (MS/MS) modes.

MS and MS/MS peak lists were generated using the FlexAnalysis 3.3 software (Bruker Daltonics), with a quality factor threshold of 30 and 3 as $\mathrm{S} / \mathrm{N}$, and were individually searched using the MASCOT server (Matrix Science, London, UK; http://www.matrixscience.com/search_form_selec t.html) in NCBIprot database against Viridiplantae (or Plant ESTs) and Virus. The protein identification parameters for peptide mass fingerprinting (PMF) searches were: $150 \mathrm{ppm}$ mass tolerance, 1 missed cleavage and carbamidomethylation of cysteine residues as fixed modification and oxidation of methionine residues as variable modification. For MS/ MS, the parameters used were the same described for PMF with an ion mass tolerance of $0.6 \mathrm{Da}$ and charge state +1 . When $\mathrm{pI}$ and molecular mass (Mw) were not available, these values were calculated using ExPASy Compute $\mathrm{pl} / \mathrm{Mw}$ tool (http://ca.expasy.org/tools/pi_tool.html). The cutoff value for the Probability Based Mowse score calculated by MASCOT (at $p<0.05$ ) was used to accept the identification.

\section{Results and Discussion}

In the present study, the effect of ToBMV infection in protein accumulation in chloroplasts of $N$. benthamiana plants was analyzed by $2-\mathrm{DE}$ and mass spectrometry. Inoculated plants showed typical symptoms, including veinal clearing, mottling, leaf distortion and stunting [7] (Fig. 1). Leaf samples from infected and control plants were collected and used for chloroplast isolation followed by protein extraction. The analysis of the obtained 2D maps from infected and non-infected plants showed approximately 210 spots per gel, varying in mass from 15 to $120 \mathrm{kDa}$. These results showed a number of proteins similar to those previously 
Fig. 1 Symptoms caused by ToBMV in Nicotiana benthamiana plants. (a) Infected plant, showing necrotic spot in inoculated leaves, vein clearing and top distortion in upper leaves. (b) Infected leaf showing vein clearing and mottling. (c) Healty $N$. benthamiana plant

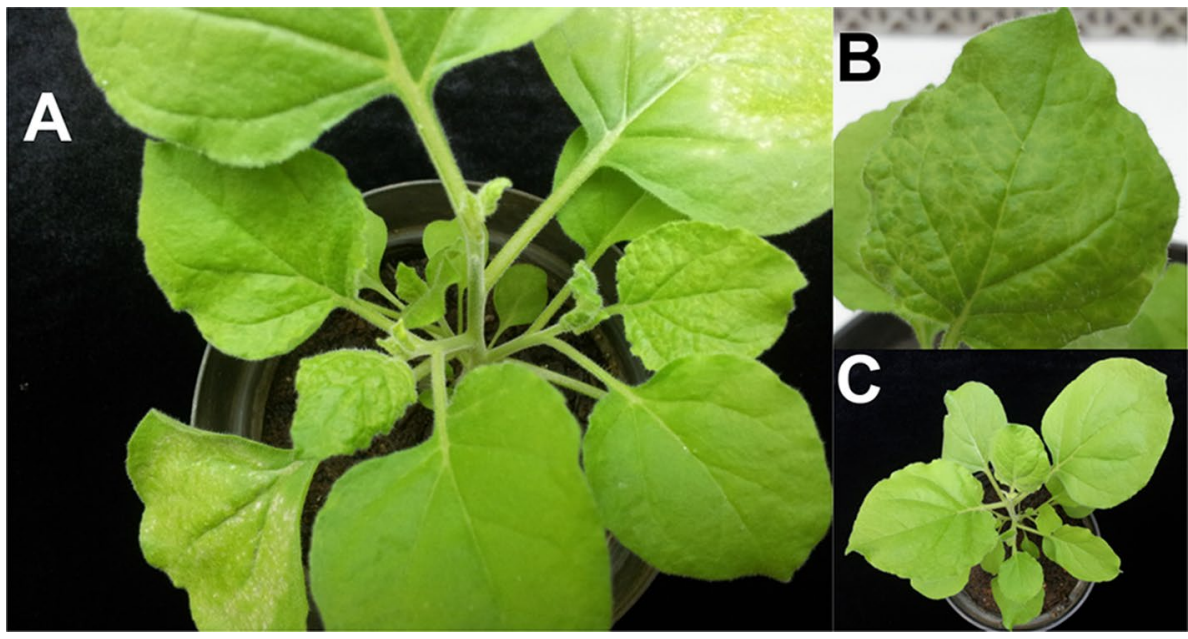

described for $N$. bethamiana chloroplasts [15]. The comparative analysis between both treatments (infected and control plants) showed a total of 36 differentially abundant proteins, including 12 increased, 17 decreased and 4 unique proteins in infected samples, as well as 3 unique proteins in control plants. All differential spots were excised for identification by mass spectrometry (MS), and a total of 16 differential proteins were identified (Table 1).

The cytopathic effect of the ToBMV on the host cell organelles involves chloroplast deformation and the induction of vesicles on its periphery. In general, it is well known that plant viral infection affects plant chloroplasts causing the reduction of several chloroplastic proteins [16, 23-27]. In this study, as expected, these proteins were, indeed, decreased in infected plants when compared to control plants, such as a Sedoheptulose-1,7-bisphosphatase (spot 130; Table 1; Fig. 2a, b) and Ribulose 1,5-bisphosphate carboxylase/oxygenase large subunit (RubL) (Spot 211; Table 1; Fig. 2a), which was unique to control plants. The lower abundance of Sedoheptulose-1,7-bisphosphatase and RubL in infected plants was previously described in different plant-pathogen interactions [28, 29], and it has been shown that oxidative alterations affect the photosynthetic proteins causing their degradation during stress [30, 31]. This is consistent with the low levels of these proteins during PMMoV-N. benthamiana interaction [15] and also with the data obtained in our study. These results suggest that ToBMV also compromises the abundance of chloroplastassociated proteins and affects the photosynthetic apparatus.

Interestingly, among the increased proteins in plants infected by ToBMV was a mixture of proteins, which included Trigger factor-like protein and ATP synthase $\beta$ subunit (spot 18; Table 1; Fig. 2a, b). It has been reported that ATP synthase $\beta$ subunit interacts with viral proteins [16]. Moreover, the Trigger factor-like protein may help viral infection, since it is a folding chaperone [32, 33]. Host chaperones can contribute to viral infection by interacting with viral proteins $[32,33]$. Another interesting protein is RNA polymerase beta-subunit (spot 165; Table 1; Fig. 2), which showed an increased fold change of 3.93 in infected plants when compared to the control. The involvement of this enzyme in viroid replication has been reported. Plant viroids, which have circular RNAs, encode no proteins and are able to redirect a host polymerase for its replication in the chloroplast (reviewed in Ahlquist [34]). Differently, the ToBMV genome presents an ORF that encodes the RNA replicase polyprotein. It is possible that ToBMV interacts with chloroplastic RNA polymerase to change the gene expression in chloroplast genes to benefit virus infection. Therefore, these proteins are interesting candidates to further investigation to establish their role in viral pathogenesis during ToBMV infection.

It is noteworthy that some proteins were unique in infected samples. Among them are 50S ribosomal protein L6 (spot 205; Table 1; Fig. 2a), ATP synthase F1 subunit 1-mitochondrion (spot 203; Table 1; Fig. 2a), and ToBMV coat protein (spot 157 and 206; Table 1; Fig. 2a). Studies showed that the protein synthesis by chloroplasts generally can be inhibited by the virus [35], compromising even the levels of chloroplast ribosomal RNA [36]. However, it is also known that viruses recruit host ribosomal subunits to translate viral mRNAs (reviewed in Walsh and Mohr [37]). Therefore, it is possible that the abundance of $50 \mathrm{~S}$ ribosomal protein in infected plants could be caused by ToBMV to promote viral infection. 


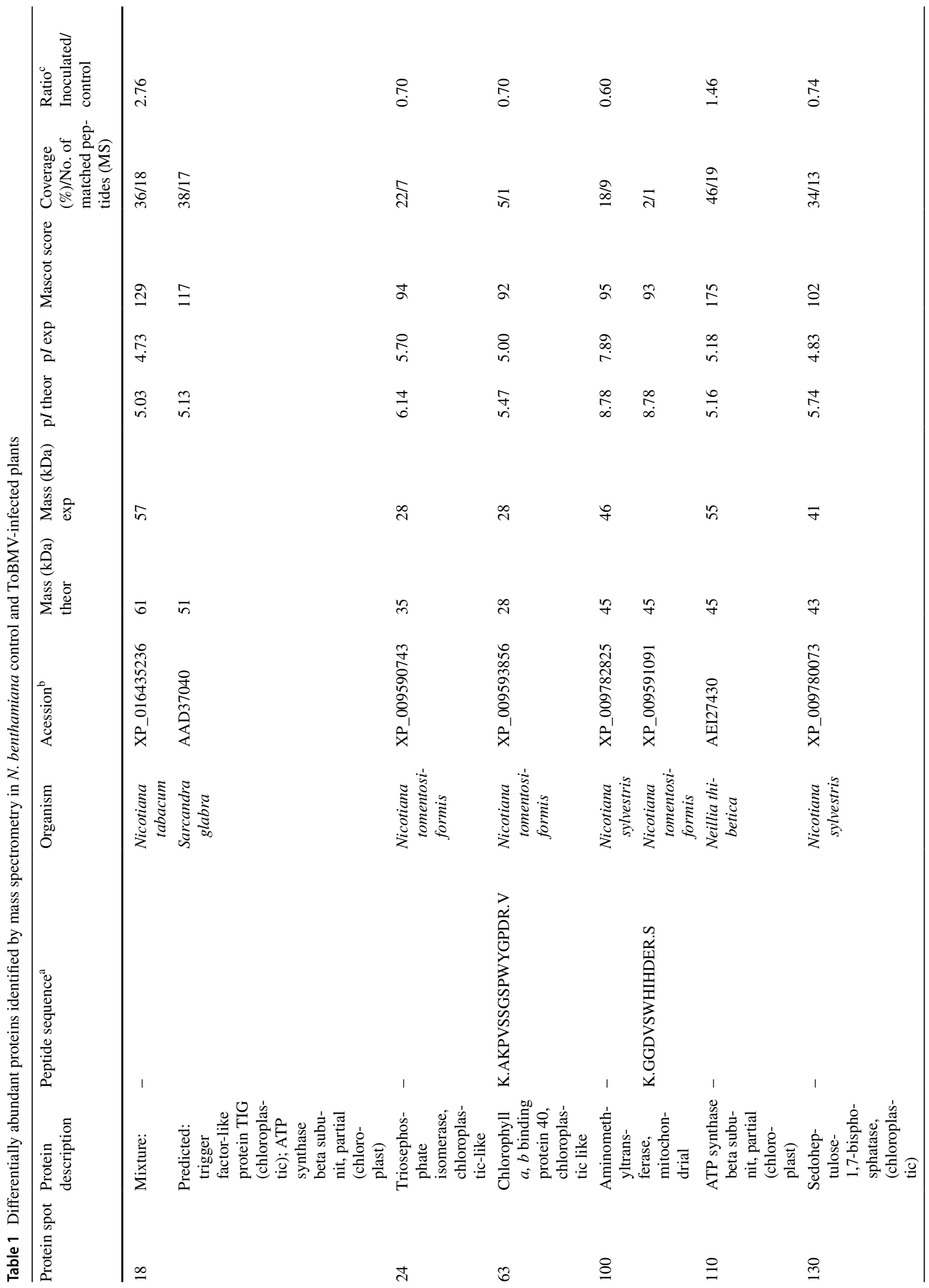




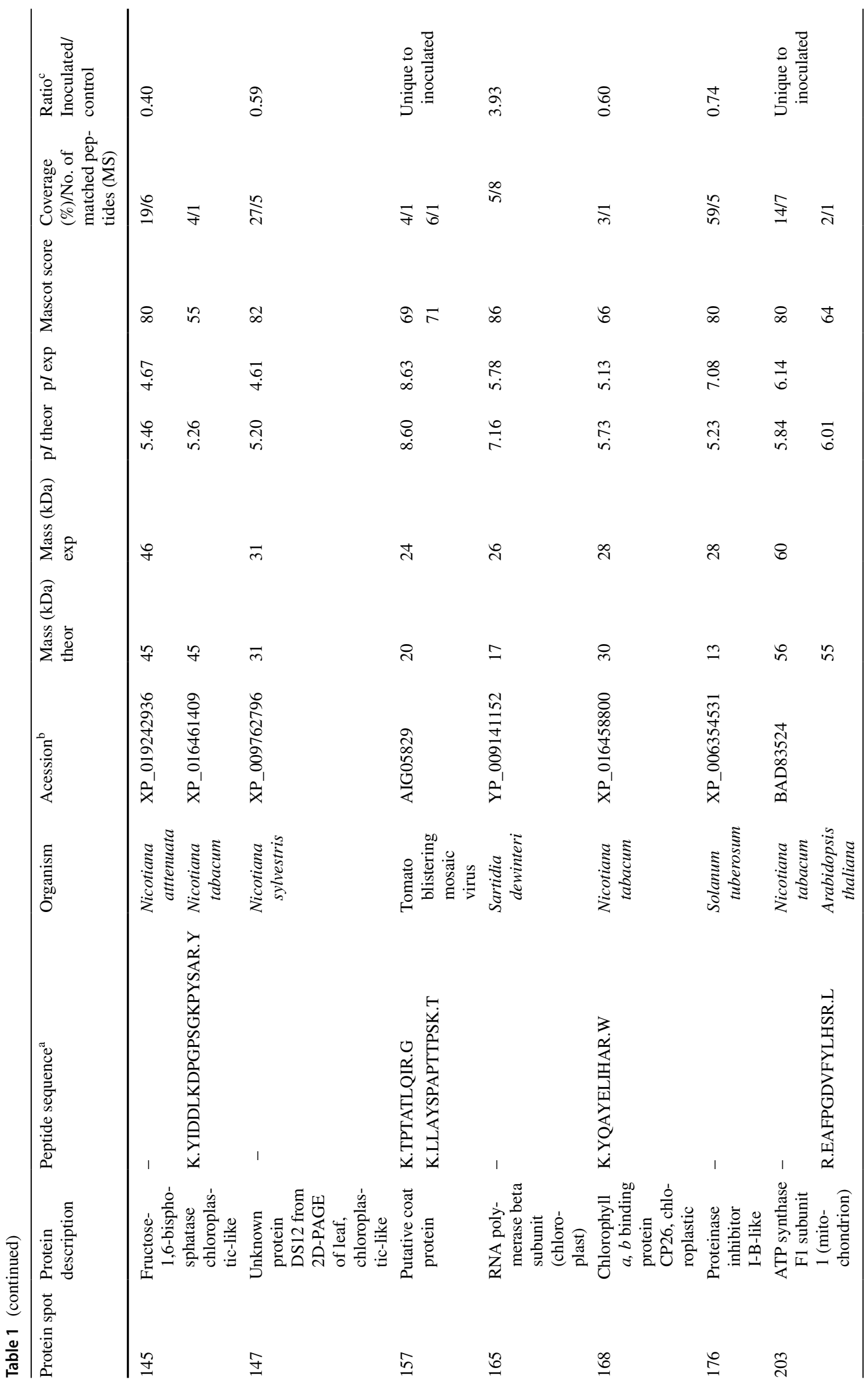


296

E. Megias et al.

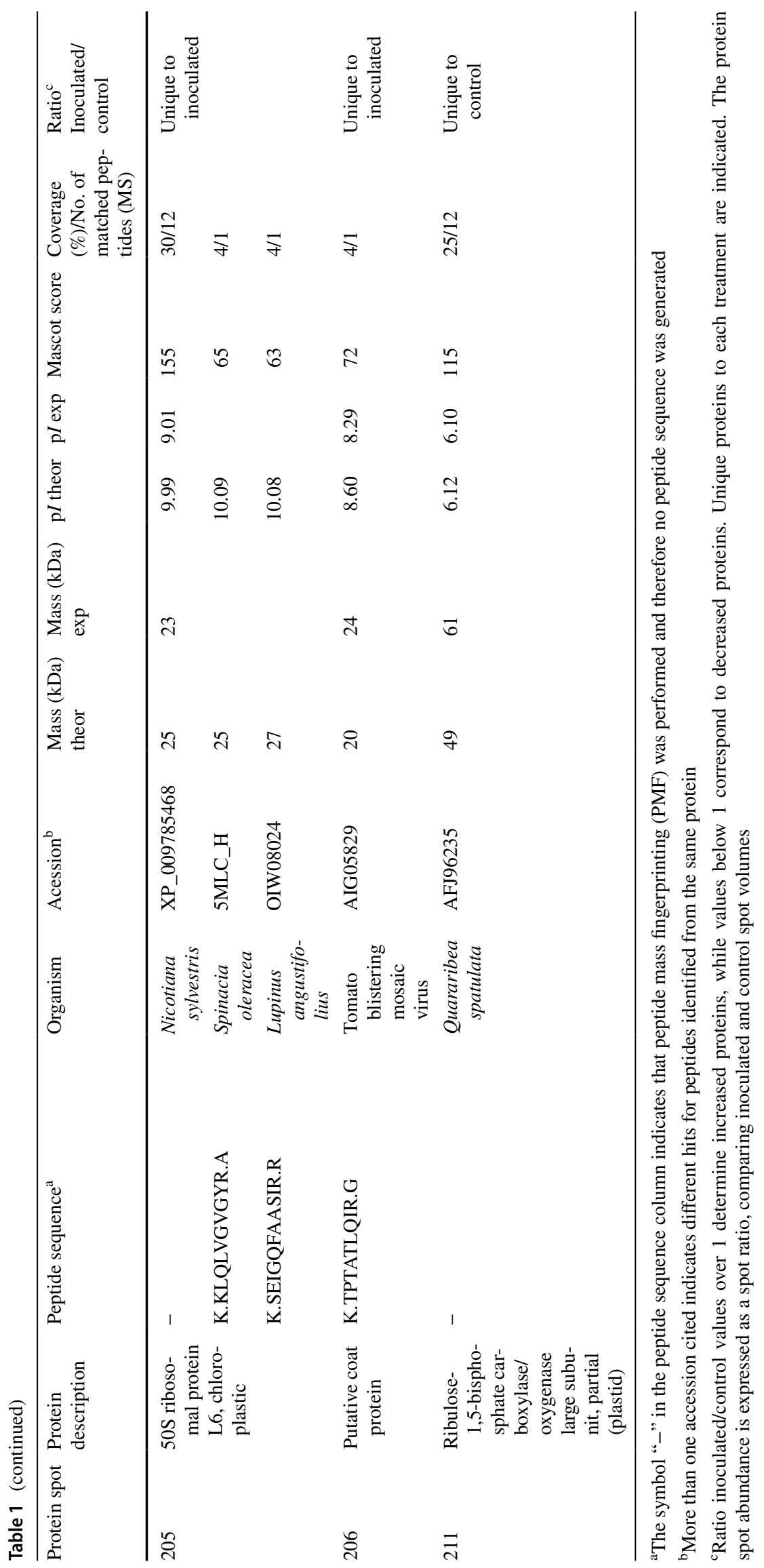

Springer 
A $\mathrm{kDa}$

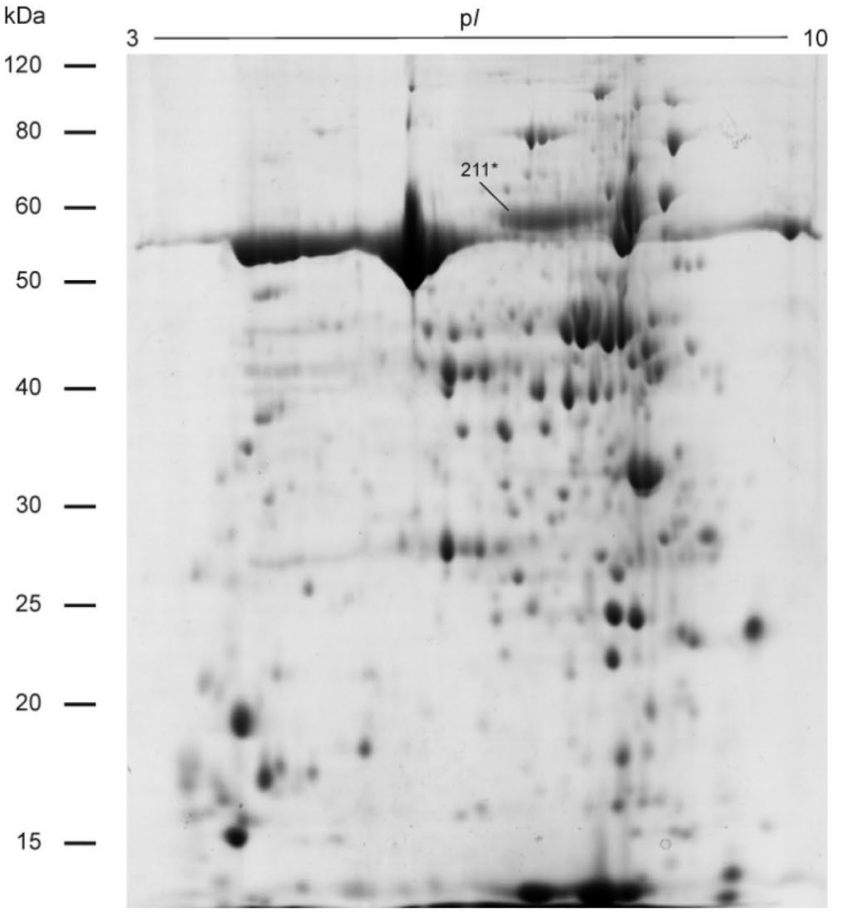

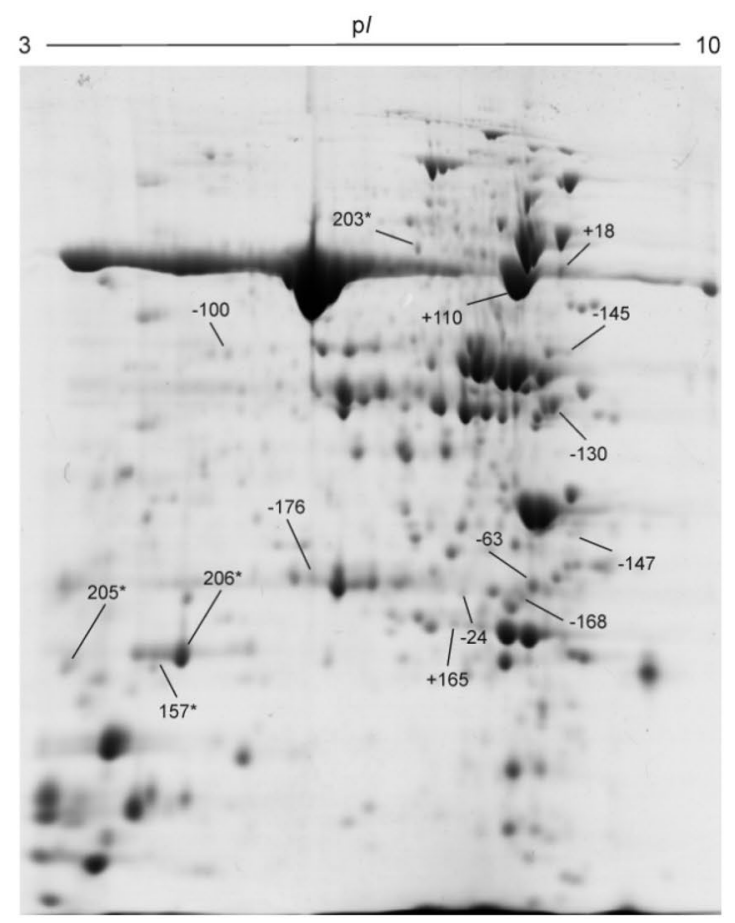

B

\section{Differentially Abundant proteins}

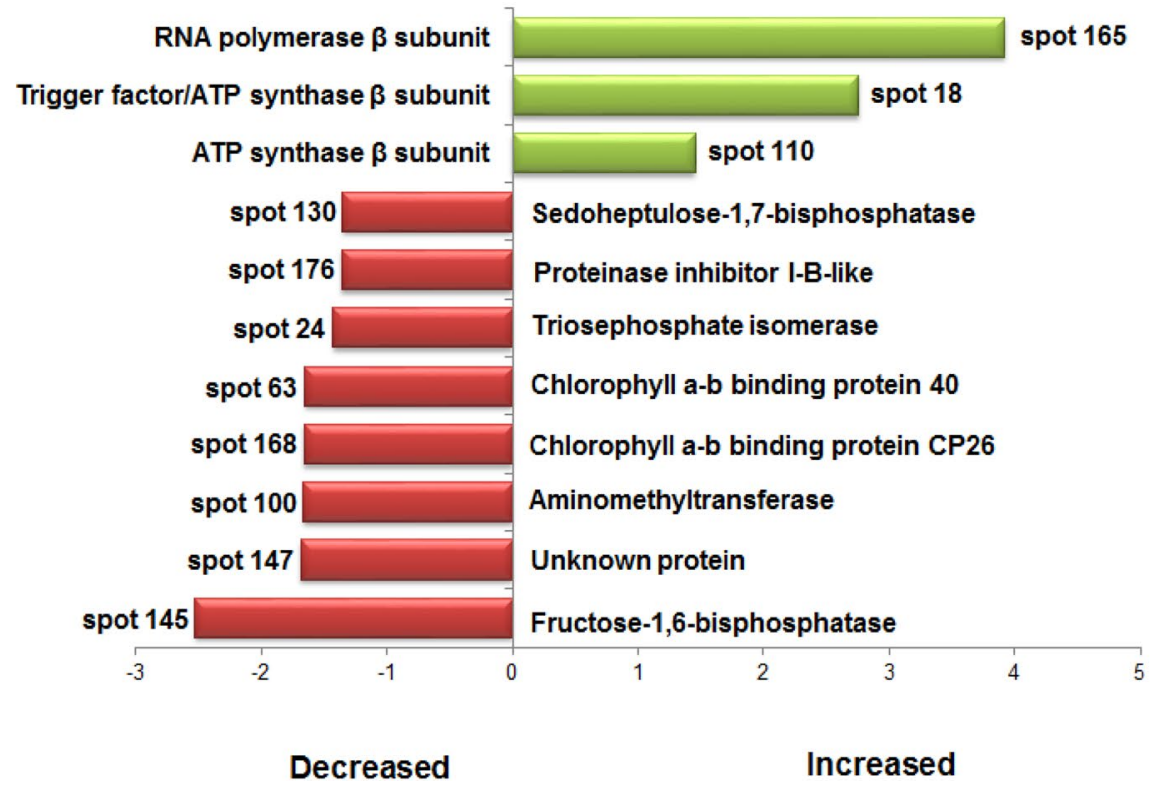

Fig. 2 (a) 2D maps of chloroplast preparations from Nicotiana benthamiana plants in the control (left) condition and inoculated with ToBMV (right). The symbols + and - indicate increased and decreased proteins, respectively, when compared to the control. The
* symbol indicates unique proteins to one of the conditions. (b) The graph represents the fold change of differential proteins in plants inoculated with ToBMV when compared to the control. The unique proteins of each condition are not shown 


\section{Conclusions}

This is the first comparative report showing chloroplast proteins involved in the plant response to ToBMV infection. The results indicate that this virus has an effect similar to other viruses, affecting severely the protein metabolism in chloroplasts. Proteins potentially involved in the infection process were also identified, including an RNA polymerase beta-subunit and a $50 \mathrm{~S}$ ribosomal protein L6, which were highly abundant or unique in infected tissues analyzed. Furthermore, this study identified some proteins that may be targets of a direct interaction with viral proteins, such as ATP synthase $\beta$ subunit and Trigger factor-like protein. The identification of these targets is highly important in understanding the pathogenicity of ToBMV since they may be recruited by the virus to favor the infection. Therefore, it would be interesting to further investigate these chloroplast-related proteins to elucidate their roles in ToBMV pathogenesis.

Acknowledgements This work was sponsored by Embrapa, UnB, CAPES and CNPq.

\section{Compliance with Ethical Standards}

Conflict of interest Authors have no conflict of interest to declare.

\section{References}

1. Hull R (2002) CHAPTER 1 - introduction. In: Matthews' plant virology, 4th edn. Academic Press, London, pp 1-12 https://doi. org/10.1016/B978-012361160-4/50052-9

2. Ribeiro S, Kitajima E, Oliveira R, Koenig R (1996) A strain of eggplant mosaic virus isolated from naturally infected tobacco plants in Brazil. Plant Dis 80(4):446-449

3. Alexandre MAV, Duarte LML, Rivas EB, Chagas CM, Barradas MM, Koenig R (2000) Petunia vein banding virus: characterization of a new tymovirus from petunia $\times$ hybrida. Plant Dis 84(7):739-742. https://doi.org/10.1094/pdis.2000.84.7.739

4. Crestani O, Kitajima E, Lin M, Marinho V (1986) Passion fruit yellow mosaic virus, a new tymovirus found in Brazil. Phytopathology 76(9):951-955

5. Nicolini C, Pio-Ribeiro G, Andrade GP, Melo FL, Oliveira VC, Guimarães FC, Resende RO, Kitajima EW, Rezende JAM, Nagata $\mathrm{T}$ (2012) A distinct tymovirus infecting cassia hoffmannseggii in Brazil. Virus Genes 45(1):190-194. https://doi.org/10.1007/s1126 2-012-0750-9

6. Nicolini C, Inoue-Nagata AK, Nagata T (2015) Complete genome sequence of a proposed new tymovirus, tomato blistering mosaic virus. Arch Virol 160(2):609-612. https://doi.org/10.1007/s0070 5-014-2289-7

7. de Oliveira VC, Nagata T, Guimarães FC, Ferreira FA, Kitajima EW, Nicolini C, de Oliveira Resende R, Inoue-Nagata AK (2013) Characterization of a novel tymovirus on tomato plants in Brazil. Virus Genes 46(1):190-194. https://doi.org/10.1007/s1126 2-012-0830-x
8. Blawid R, Hayashi EAI, Rezende JAM, Kitajima EW, Nagata $\mathrm{T}$ (2016) A highly divergent isolate of tomato blistering mosaic virus from Solanum violaefolium. Virus Genes 52(2):294-298. https://doi.org/10.1007/s11262-016-1288-z

9. Melo FL, Fernandes JEA, Ribeiro BM, Ribeiro SG (2014) Complete genome sequence of a tobacco-infecting, tomato-blistering mosaic virus. Genome Announcements 2(4):e00701-e00714.

10. Ferrand L, Nome C, Orílio AF, García ML, Nagata T, Ronco LB, Dal Bó E (2015) First report of tomato blistering mosaic virus infecting tomato in Argentina. Plant Dis 100(5):1026. https://doi. org/10.1094/pdis-07-15-0782-pdn

11. Verchot $\mathbf{J}$ (2011) Wrapping membranes around plant virus infection. Curr Opin Virol 1(5):388-395. https://doi.org/10.1016/j. coviro.2011.09.009

12. Di Carli M, Benvenuto E, Donini M (2012) Recent insights into plant-virus interactions through proteomic analysis. J Prot Res 11(10):4765-4780. https://doi.org/10.1021/pr300494e

13. Peltier J-B, Friso G, Kalume DE, Roepstorff P, Nilsson F, Adamska I, van Wijk KJ (2000) Proteomics of the chloroplast: systematic identification and targeting analysis of lumenal and peripheral thylakoid proteins. Plant Cell 12(3):319-342

14. Peltier J-B, Emanuelsson O, Kalume DE, Ytterberg J, Friso G, Rudella A, Liberles DA, Söderberg L, Roepstorff P, von Heijne G, van Wijk KJ (2002) Central functions of the lumenal and peripheral thylakoid proteome of Arabidopsis determined by experimentation and genome-wide prediction. Plant Cell 14(1):211-236. https://doi.org/10.1105/tpc.010304

15. Pineda M, Sajnani C, Barón M (2010) Changes induced by the Pepper mild mottle tobamovirus on the chloroplast proteome of Nicotiana benthamiana. Photosynth Res 103(1):31. https://doi. org/10.1007/s11120-009-9499-y

16. Zhao J, Zhang X, Hong Y, Liu Y (2016) Chloroplast in plant-virus interaction. Front Microbiol 7:1565. https://doi.org/10.3389/fmicb .2016 .01565

17. Brizard JP, Carapito C, Delalande F, Van Dorsselaer A, Brugidou C (2006) Proteome analysis of plant-virus interactome: comprehensive data for virus multiplication inside their hosts. Mol Cell Proteomics 5(12):2279-2297

18. Boatwright JL, Pajerowska-Mukhtar K (2013) Salicylic acid: an old hormone up to new tricks. Mol Plant Pathol 14(6):623-634. https://doi.org/10.1111/mpp.12035

19. Wasternack C, Hause B (2013) Jasmonates: biosynthesis, perception, signal transduction and action in plant stress response, growth and development. An update to the 2007 review in annals of botany. Ann Bot 111(6):1021-1058. https://doi.org/10.1093/ aob/mct067

20. Alazem M, Lin N-S (2015) Roles of plant hormones in the regulation of host-virus interactions. Mol Plant Pathol 16(5):529-540. https://doi.org/10.1111/mpp.12204

21. Kubis SE, Lilley KS, Jarvis P (2008) Isolation and preparation of chloroplasts from Arabidopsis thaliana plants. In: Posch A (ed) 2D PAGE: sample preparation and fractionation. Humana Press, Totowa, pp 171-186 https://doi.org/10.1007/978-1-60327 $-210-0 \_16$

22. Carmo LST, Resende RO, Silva LP, Ribeiro SG, Mehta A (2013) Identification of host proteins modulated by the virulence factor AC2 of Tomato chlorotic mottle virus in Nicotiana benthamiana. Proteomics 13(12-13):1947-1960. https://doi.org/10.1002/ pmic. 201200547

23. Seo S, Okamoto M, Iwai T, Iwano M, Fukui K, Isogai A, Nakajima N, Ohashi Y (2000) Reduced levels of chloroplast FtsH protein in tobacco mosaic virus-infected tobacco leaves accelerate the hypersensitive reaction. Plant Cell 12(6):917-932

24. Bhat S, Folimonova SY, Cole AB, Ballard KD, Lei Z, Watson BS, Sumner LW, Nelson RS (2013) Influence of host chloroplast proteins on tobacco mosaic virus accumulation and intercellular 
movement. Plant Physiol 161(1):134-147. https://doi.org/10.1104/ pp. 112.207860

25. Mochizuki T, Ogata Y, Hirata Y, Ohki ST (2014) Quantitative transcriptional changes associated with chlorosis severity in mosaic leaves of tobacco plants infected with Cucumber mosaic virus. Mol Plant Pathol 15(3):242-254

26. Kundu S, Chakraborty D, Kundu A, Pal A (2013) Proteomics approach combined with biochemical attributes to elucidate compatible and incompatible plant-virus interactions between Vigna mungo and Mungbean yellow mosaic India Virus. Proteome Sci 11:15. https://doi.org/10.1186/1477-5956-11-15

27. Wu L, Wang S, Chen X, Wang X, Zu X, Chen Y (2013) Proteomic and phytohormone analysis of the response of maize (Zea mays L.) seedlings to sugarcane mosaic virus. PLoS ONE 8(7):e70295. https://doi.org/10.1371/journal.pone.0070295

28. Pan X, Zhu B, Luo Y, Fu D (2013) Unraveling the protein network of tomato fruit in response to necrotrophic phytopathogenic Rhizopus nigricans. PLoS ONE 8(9):e73034. https://doi.org/10.1371/ journal.pone.0073034

29. Ji X, Gai Y, Zheng C, Mu Z (2009) Comparative proteomic analysis provides new insights into mulberry dwarf responses in mulberry (Morus alba L.). Proteomics 9(23):5328-5339. https://doi. org/10.1002/pmic.200900012

30. Vass I, Cser K, Cheregi O (2007) Molecular mechanisms of light stress of photosynthesis. Ann NY Acad Sci 1113:114-122. https ://doi.org/10.1196/annals.1391.017
31. Houtz RL, Portis AR (2003) The life of ribulose 1,5-bisphosphate carboxylase/oxygenase-posttranslational facts and mysteries. Arch Biochem Biophys 414(2):150-158

32. Ellis RJ (2013) Assembly chaperones: a perspective. Philos Trans R Soc Lond B Biol Sci 368(1617):20110398. https://doi. org/10.1098/rstb.2011.0398

33. Gorovits R, Moshe A, Ghanim M, Czosnek H (2013) Recruitment of the host plant heat shock protein 70 by tomato yellow leaf curl virus coat protein is required for virus infection. PLoS ONE 8(7):e70280. https://doi.org/10.1371/journal.pone.0070280

34. Ahlquist P (2002) RNA-dependent RNA polymerases, viruses, and RNA silencing. Science 296(5571):1270-1273. https://doi. org/10.1126/science.1069132

35. Pérez-Bueno ML, Rahoutei J, Sajnani C, García-Luque I, Barón M (2004) Proteomic analysis of the oxygen-evolving complex of photosystem II under biotec stress: studies on Nicotiana benthamiana infected with tobamoviruses. Proteomics 4(2):418-425. https ://doi.org/10.1002/pmic.200300655

36. Fraser RS (1969) Effects of two TMV strains on the synthesis and stability of chloroplast ribosomal RNA in tobacco leaves. Mol Gen Genet 106(1):73-79

37. Walsh D, Mohr I (2011) Viral subversion of the host protein synthesis machinery. Nat Rev Microbiol 9(12):860-875. https://doi. org/10.1038/nrmicro2655 